\title{
PRIORITIZING A NEW SET OF ENVIRONMENTAL MANAGEMENT SYSTEM ACTIVITIES WITH FUZZY TOPSIS METHOD
}

\author{
Ulviye POLAT
}

Filiz GÜRTUNA

\begin{abstract}
Environmental Management System (EMS) studies conducted today are activities where enterprises plan, implement, control and monitor measures related to their activities that can impact the environment, and systematically and sustainably carry out activities aimed at preserving the environment. Given the limited resources of enterprises such as workforce, money, time, machinery and equipment, it is important for enterprises to prioritize their activities so that EMS's work effectively. In this study, a list of environmental activities was primarily established with the aim of determining the EMS activities to be undertaken by enterprises or evaluating existing environmental activities. An approach for determining prioritized activities was developed from the created activity list according to the evaluation criteria appropriate to the operating conditions of enterprises.
\end{abstract}

Keywords: Environmental Management System, E-FMEA, Fuzzy TOPSIS

\section{Yeni Bir Çevre Yönetim Sistemi Aktiviteleri Grubunun Bulanık TOPSIS Metodu ile Önceliklendirilmesi}

Öz: Günümüzde yürütülen çevre yönetim sistemi (ÇMS) çalışmaları, işletmelerin çevreyi etkileyebilecek faaliyetleriyle ilgili önlemlerini planladığı, uyguladığı, kontrol ettiği ve izlediği, sistemli ve sürdürülebilir bir şekilde çevreyi korumaya yönelik faaliyetlerini gerçekleştirdikleri çalışmalardır. İşletmelerin iş gücü, para, zaman, makine-ekipman gibi kısıtlı kaynakları göz önünde bulundurulduğunda çevre yönetim sistemi çalışmalarını etkin yürütebilmek için hangi faaliyetlerin önceliklendirilmesi gerekliliği önemli olmaktadır. Bu çalışmada öncelikli olarak, işletmelerin kuracakları çevre yönetim sistemi faaliyetlerini belirleme veya mevcut çevresel faaliyetlerini gözden geçirme amacı ile bir çevresel faaliyet listesi oluşturulmuştur. Oluşturulan faaliyet listesinden, işletme koşullarına uygun değerlendirme kriterlerine göre öncelikli faaliyetlerin belirlenmesi konusunda bir yaklaşım geliştirilmiştir.

Anahtar Kelimeler: Çevre Yönetim Sistemi, E-FMEA, Bulanık TOPSIS

\footnotetext{
${ }^{*}$ Tekirdağ Namık Kemal University, Çorlu Faculty of Engineering, Department of Industrial Engineering, 59860,

***Tekirdağ Namık Kemal University, Çorlu Faculty of Engineering, Department of Industrial Engineering, 59860, Çorlu, Tekirdağ

Correspondence Author: Ulviye Polat (upolat@nku.edu.tr)
} 


\section{INTRODUCTION}

Environmental problems arising due to the increasing density of population and industrialization around the world are becoming more and more severe. These environmental threats appear in the form of chemical emissions, hazardous and non-recyclable wastes, industrial processes that pollute natural resources, irresponsible depletion of resources, reduction of green spaces, and increased energy needs around the world. Today, it has become very important that both industrial enterprises and individuals are aware of environmental problems, establish necessary measures to protect the environment, implement these measures, and ensure the continuity of the applications.

In industrial enterprises, there is an increase in efforts on Environmental Management System (EMS), in particular to reduce the environmental damage of business activities. Enterprises sensitive to environmental protection perform practices such as establishment of procedures and instructions for environmental policy and protection of the environment, effective waste and resource management, environmental dimensions and effects analysis systems, and environmental performance monitoring systems. However, the important issue should be to ensure the sustainability of these activities. Following the 1972 Stockholm United Nations Environment Conference, the public has shown great sensitivity to serious environmental problems and five environmental action plans have been implemented in Europe. With the 1992 United Nations Environment Conference in Rio de Janeiro, the world has rapidly adopted the principle of "sustainable development". It has been understood that development and environment are not opposing concepts, but rather complementary elements (Karaer and Pusat, 2002).

The International Standards Organization (ISO) presents the 14001 EMS standard as a guide to sustainable improvement of environmental performance for an organization. In this study, the established environmental activities were determined utilizing the scope of ISO 14001 EMS standard along with many other elements. Firstly, in the literature, studies on the implementation of ISO 14001 EMS standard were examined. The studies examined are listed in Table 1, where it can be seen that the studies are generally within the scope of examining the applications of ISO 14001 in the enterprises and their effects on environmental performance. In this study, while determining the environmental activities to be examined, the main issues forming the standard are detailed in the activity list.

\section{Table 1. Studies examined in the literature based on ISO 14001 EMS for determination of} environmental activities

\begin{tabular}{|c|c|c|}
\hline Year & Author & Scope of Study \\
\hline 2000 & Mohammed M. & $\begin{array}{l}\text { The role of EMS based on ISO } 14001 \text { in improving environmental } \\
\text { performance in the Central Japan Region, its implementation process, its } \\
\text { impact on regional environmental management, its impact on the relationship } \\
\text { between EMS stakeholders }\end{array}$ \\
\hline 2005 & $\begin{array}{l}\text { Gonzalez.-Benito J. and } \\
\text { Gonzalez.-Benito O. }\end{array}$ & Impact of stakeholder pressure on ISO 14001 EMS applications \\
\hline 2011 & Qi G.Y. et al. & Impact of stakeholders on ISO 14001 EMS deployment in China \\
\hline 2012 & Disterheft A. et al. & ISO 14001 EMS implementation processes in European universities \\
\hline 2012 & Lo C.K.Y. et al. & $\begin{array}{l}\text { The impact of the adoption of ISO } 14001 \text { EMS in the fashion and textile } \\
\text { industry }\end{array}$ \\
\hline 2014 & Kanyimba A.T. et al. & $\begin{array}{l}\text { Investigation of ISO } 14001 \text { EMS effectiveness in primary schools in South } \\
\text { Africa }\end{array}$ \\
\hline
\end{tabular}


Table 1. (continued)

\begin{tabular}{|c|c|c|}
\hline Year & Author & Scope of Study \\
\hline 2015 & Amores-Salvado J. et al. & Relationship between EMS and environmental innovation practices \\
\hline 2015 & Erdas C. et al. & $\begin{array}{l}\text { Linking the ecological footprint of the Limassol Port in the Mediterranean to } \\
\text { the ISO } 14001 \text { EMS targets }\end{array}$ \\
\hline 2015 & Phan T.N. and Baird K. & $\begin{array}{l}\text { Impact of enforced applications and the scope of EMS on environmental } \\
\text { performance in various industries in Australia }\end{array}$ \\
\hline 2015 & Wagner M. & The effect of EMS on employee satisfaction \\
\hline 2016 & Daddi T. et al. & Effects of EMS practices on the firm \\
\hline 2016 & Feng T. et al. & $\begin{array}{l}\text { Examining the relationship between EMS implementation and financial } \\
\text { performance in manufacturing companies in China }\end{array}$ \\
\hline 2016 & Mazzi A. et al. & $\begin{array}{l}\text { Investigation of advantages and disadvantages of ISO } 14001 \text { EMS } \\
\text { applications in enterprises }\end{array}$ \\
\hline 2016 & Oliveira J.A. et al. & $\begin{array}{l}\text { Interaction and relationship between ISO } 14001 \text { EMS and Clean Production } \\
(\mathrm{CP}) \text { in Brazil }\end{array}$ \\
\hline 2017 & Mazzi A. et al. & Implementation of 'Life Cycle Assessment (LCA)' method in EMS \\
\hline 2018 & $\begin{array}{l}\text { Martins F. and Fonseca } \\
\text { L. }\end{array}$ & $\begin{array}{l}\text { Comparison of ISO 14001:2005 and EMAS (Eco-Management and Audit } \\
\text { Scheme) contents }\end{array}$ \\
\hline 2018 & Orcos R. et al. & Examination of ISO 14001 EMS application differences in 49 countries \\
\hline 2019 & Treacy R. et al. & $\begin{array}{l}\text { Monitoring the performances of certified and non-certified companies } \\
\text { applying ISO 14001 EMS in the UK and Ireland }\end{array}$ \\
\hline
\end{tabular}

In this study, fuzzy TOPSIS method, which is one of the multi-criteria decision making approaches, is used for the analysis of the determined environmental activities. There are many studies using 'multi-criteria decision making approaches' in the field of environmental management. Balana et al. (2010) conducted a multi-criteria study on the sustainability of forests in the mountainous regions of Tigray province of northern Ethiopia. Khalili and Duecker (2013) presented model practices and scenarios for sustainable EMS and came up with sustainable production and pollution prevention strategies according to the criteria defined by internal and external stakeholders of the institution they studied using the Electre III method. Guerrero-Baena et al. (2015) conducted a decision making analysis method to select the EMS alternative that maximizes the market value of a company. In the study, alternatives of ISO 14001 certification, EMAS certification and EMS without certification were evaluated. He et al. (2017) identified the factors affecting the ecological fragility in a selected region in China and evaluated the effects of these factors using a multi-criteria decision making method. Interlenghi et al. (2017) conducted a multi-criteria study among the social and environmental factors that affect the sustainability of biodiesel production chains and tried to determine the most effective factors. Ligus and Peternek (2018) used fuzzy AHP and TOPSIS methods together for the evaluation of renewable energy technologies in Poland. Aung et al. (2019) evaluated waste management systems in the field of health in Myanmar using ANP and AHP methods. Vavrek and Chovancova (2019) used the TOPSIS method to evaluate environmental energy performance in EU countries. A study, similar to this one, in which the environmentaş activity list was formed and evaluated with a multi-criteria decision making approach was not found in the literature. In addition, in this study, the evaluation criteria used in the TOPSIS method were created and used for the first time in the context of EMS.

One of the evaluation criteria in the fuzzy TOPSIS method used in the developed approach is Environmental FMEA (E-FMEA) method. In this study, E-FMEA was used to determine the environmental risk levels of the activities. Environmental impacts are the hazards that can cause environmental problems. The environmental impacts in enterprises are determined by the experts responsible for the implementation of EMS. While determining environmental aspects, field observations, surveys and environmental records should be taken into account. Issues such as emissions, waste and waste management, resource use, working with chemicals, and environmental noise are very important from an environmental point of view (Kokangül et al., 2018). The studies conducted in the literature on the determination of environmental impacts were also examined in this study. Zackrisson (2003) examined the relationship between environmental impacts and product use and / or destruction in manufacturing. Darbra et al. (2005) 
developed an ISO 14001 EMS-based methodology for identifying important environmental elements at sea ports. Marazza et al. (2010) developed a new methodology for determining the environmental aspects of a local authority in Italy. Yan and Yanli (2011) examined the environmental impact of renewable energy consumption of rural residents based on carbon emissions. Kania et al. (2014), examined the importance of environmental FMEA (E-FMEA) method and the impact of its use on environmental management. Roszak et al. (2015) developed an environmental approach to the probability, severity and occurrence scales used in the FMEA. Zeng et al. (2015) used the FMEA method by establishing an approach for OHSAS 18001, ISO 14001 and ISO 9001 integration. Silva and Lopes (2017) examined the environmental aspects and impacts of hazardous waste incineration plants. Chung et al. (2019) used the fuzzy inference approach in environmental risk assessment and mapping for air pollutants in Taiwan.

In this study, the environmental activities required to monitor the existing EMS processes and activities of enterprises or to establish an effective EMS system were initially identified. The specified activities can be taken as they are or adapted and used as guidelines for an enterprise operating in any sector. In order to be able to effectively carry out environmental conservation activities, which requires significant amounts of money, time, machinery, equipment and expertise; businesses need to make effective use of their resources. In this study, a methodology was developed to identify which activities should be given attention and priority based on the resource constraints of enterprises.

In this study, environmental activity list was formed as a result of ISO 14001 EMS standard, requirements in the current environmental legislation, studies in the literature, expert opinion and field examination. The preparation of the environmental activity list by consolidating the mentioned methods contributes to the literature by being the first in terms of analysis with fuzzy TOPSIS method, which is a multi-criteria decision making approach by creating evaluation criteria that have not been used before in academic studies.

\section{METHODOLOGY}

The approach developed in this study for the establishment or implementation of an effective EMS is shown in the workflow in Figure 1.

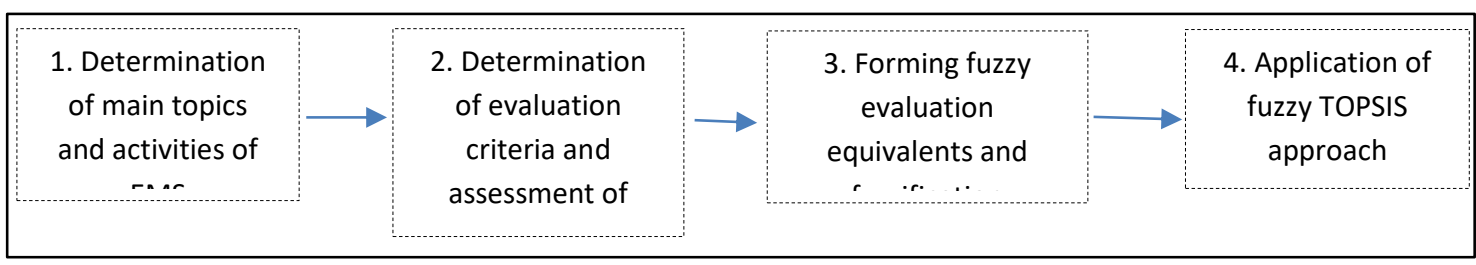

Figure 1:

Workflow of developed approach

\subsection{Determination of Main Topics and Activities of EMS}

In order to plan the works on environmental management in a workplace or to control the effectiveness of an existing work, it must first be decided which activities need to be carried out. While determining these activities, ISO 14001 EMS standard, studies conducted by enterprises on environmental management, current situation analyses, field analyses, environmental aspect and impact analyses made by environmental experts or environmental consultants, current legal legislation, academic publications, and studies conducted by social collaborations and ministries of environment should be reviewed. Based on the results of this review, the enterprise evaluates its status and obtains a pool of activities that includes what needs to be done. 
When conducting a current status analysis, problem analysis methods such as environmental risk analysis, cause-and-effect analysis, Pareto analysis, examination of past environmental statistics, and brain storming can also be useful.

It is important that environmental activities are determined by a team led by the environmental experts of the enterprise or an environmental consultant who is familiar with the operation. Environmental experts, environmental technicians, environmental emergency team members, and people working in operational units (production, logistics, quality etc.) can be in the team. Since environmental activities will include technical issues such as operation of the treatment plant, emissions analysis, waste management, environment officer of the company or in its absence, the manager responsible for the environmental department leading the team will improve the effectiveness of the results.

While environmental activities are determined, main topics in environmental management such as waste management, emission monitoring etc. are determined. Then, environmental activities relevant to the enterprise are grouped according to these main topic headings. Similar environmental activities are combined into a single activity. For example, instead of writing collection of paper waste, collection of chemical wastes, or collection of glass wastes from work sites, these are grouped in the same activity as 'collection of wastes from work sites'. What is important here is that no topic that needs attention is left out. If there is a significant application difference between activities, these are written as separate activities.

When grouping environmental activities, it would be beneficial for the team to use the 'Relevance Proximity Diagram' or 'Nominal Grouping' techniques.

\subsection{Determination of Evaluation Criteria and Evaluation of Activities}

In enterprises, usually an action plan is prepared for environmental management activities. What activities need to be initiated, beginning time of these activities and the responsible officers are determined in this action plan. Often, enterprises analyze the environmental dimensions and impacts, score environmental factors, and begin to prepare their action plans starting with the high-score factors. However, it is also necessary to take into consideration important factors such as the duration of the operation, cost, number of personnel required, which affect the implementation of action plans. These factors may vary according to the resources of each enterprise and the expectations of the management.

In this study, to evaluate the environmental activities according to the determined criteria, TOPSIS method, which is one of the multi-criteria decision making approaches and which yields the shortest distance to the positive ideal solution point and the farthest distance to the negative ideal solution point was used. Fuzzy TOPSIS was preferred in this study as it was not used in the previous studies similar to this one, where it was used in the evaluation of a newly created environmental activity list and as the method yielded a ranking according to the significance weights. Using fuzzy TOPSIS was preferred due to the uncertainty as according to the evaluation criteria the result of the activities includes subjectivity being based on expert opinion.

While the evaluation criteria are determined, the views and opinions of managers and environmental experts who are in the best position to comment on business conditions are taken. Evaluation criteria may vary from sector to sector, or even in the same sector according to the resource capacities and strategies of the businesses.

In this study, 'ease of application of improvement activities, implementation cost of improvement activities, E-FMEA score, environmental sustainability impact and expertise requirement for improvement activities' were determined as evaluation criteria. These criteria were used for the first time in an academic study in the evaluation of environmental activities.

The E-FMEA method included in the evaluation criteria was used in reference to the study of Rozscak et al. (2015). E-FMEA method consists of 3 parameters: occurrence (O), severity (S), and detectability (D). Each of these parameters has a scale. These scales are adapted to the environmental system E-FMEA. Scales for O, S, and D parameters have been redefined for E- 
FMEA. The $\mathrm{O}, \mathrm{S}$ and $\mathrm{D}$ parameters are assessed and the risk priority number (RPN) is calculated by multiplying the assessed values of $\mathrm{O}, \mathrm{S}$, and $\mathrm{D}$ (Roszak et al. 2015).

In TOPSIS method, it is important to keep the number of criteria at most about 5-7 in order not to decrease the effect of evaluation criteria on the results. When the evaluation criteria are determined, their percentage values should also be determined.

When evaluating the activities of the EMS according to the determined criteria, it is necessary for the decision makers to be experts in the field. The evaluation of activities by people who are not working in the field of environmental management practices will lead to incorrect results.

Assessment scales are needed so that designated decision makers can determine the significance of activities with respect to the criteria. Common assessment scales can be created for all criteria, or separately for each criterion. Scales may be determined by collaboration of the study team led by the environmental expert.

In this study, a separate assessment scale was created for each evaluation criterion and these are presented in Table 2. A five-stage basic assessment system was established, in which all evaluation criteria, except the E-FMEA method, have significance levels increasing from 1 to 5 and the activities could easily be evaluated by the evaluators. Each activity is evaluated by the decision makers according to the scoring scale for evaluation criteria given in Table 2.

Table 2. Scoring chart for evaluation criteria

\begin{tabular}{|l|l|}
\hline Evaluation Criteria & Scoring \\
\hline 1.Ease of application & 1/very easy; 2/easy; 3/intermediate; 4/difficult; 5/very difficult \\
\hline $\begin{array}{l}\text { 2.Cost of } \\
\text { implementation }\end{array}$ & 1/very low; 2/low; 3/intermediate; 4/high; 5/very high \\
\hline 3.E-FMEA score & E-FMEA method \\
\hline 4.Sustainability impact & 1/very high; 2/high; 3/ intermediate; 4/low; 5/very low \\
\hline 5.Requirement of expertise & $1 /$ very low; 2/low; 3/ intermediate; 4/high; 5/very high \\
\hline
\end{tabular}

\subsection{Creation of Fuzzy Evaluation Equivalents and Fuzzification}

Depending on the score of each criterion, the fuzzy equivalent values related to evaluation criteria are ' $0,0,2 / 0,2,4 / 3,5,7 / 6,8,10 / 8,10,10$ '. These values were used in reference to the fuzzy equivalent values presented in the study of Paksoy et al. (2013). Table 3 shows evaluation criteria, scoring scale and fuzzy equivalents.

The evaluation results of the environmental activities according to Table 2 are transformed into the fuzzy equivalents shown in Table 3 , and the environment data to which the fuzzy TOPSIS method will be applied is prepared.

Table 3. Fuzzy equivalents for evaluation criteria

\begin{tabular}{|l|c|c|}
\hline Evaluation Criteria & Scoring & Fuzzy Equivalent Value \\
\hline 1.Ease of application & $1 / 2 / 3 / 4 / 5$ & $0,0,2 / 0,2,4 / 3,5,7 / 6,8,10 / 8,10,10$ \\
\hline $\begin{array}{l}\text { 2.Cost of } \\
\text { implementation }\end{array}$ & $1 / 2 / 3 / 4 / 5$ & $0,0,2 / 0,2,4 / 3,5,7 / 6,8,10 / 8,10,10$ \\
\hline 3.E-FMEA score & $0-20 / 21-40 / 41-100 /$ & $0,0,2 / 0,2,4 / 3,5,7 / 6,8,10 / 8,10,10$ \\
\hline $\begin{array}{l}\text { 4.Sustainability } \\
\text { impact }\end{array}$ & $101-300 /$ more than 301 & $0,0,2 / 0,2,4 / 3,5,7 / 6,8,10 / 8,10,10$ \\
\hline $\begin{array}{l}\text { 5.Requirement of } \\
\text { expertise }\end{array}$ & $1 / 2 / 3 / 4 / 5$ & $0,0,2 / 0,2,4 / 3,5,7 / 6,8,10 / 8,10,10$ \\
\hline
\end{tabular}


Before applying the fuzzy TOPSIS method, the fuzzy weights of evaluation criteria are also established. Criterion evaluation weights used in the study are shown in Table 4.

Table 4. Fuzzy weights of evaluation criteria

\begin{tabular}{|l|l|}
\hline Criteria & Criterion Evaluation Weight \\
\hline Very Low (VL) & $0,0,0.2$ \\
\hline Low (L) & $0,0.2,0.4$ \\
\hline Medium (M) & $0.3,0.5,0.7$ \\
\hline High (H) & $0.8,0.8,1$ \\
\hline Very High $(\mathrm{VH})$ & $0.8,1,1$ \\
\hline
\end{tabular}

The criterion evaluation weights indicated in Tablo 4 were intuitively constructed based on the field experience of the lead author of the study.

\subsection{Implementation of Fuzzy TOPSIS Approach}

The fuzzy TOPSIS method is a method that assists group decision making processes in fuzzy environments. In order for the method to be applied, decision makers, decision criteria and alternatives are created. Fuzzy TOPSIS method is based on the notion that decision criteria used by decision makers in evaluating alternatives can have different weights. With the help of fuzzy TOPSIS, decision-makers' decision criteria and evaluations of alternatives are transformed into triangular or trapezoidal fuzzy numbers. The normalized fuzzy decision matrix, weighted normalized fuzzy decision matrix, weighted normalized matrix, fuzzy positive and negative ideal solution sets are computed respectively. After determining the ideal distances, the closeness coefficient of each alternative is calculated. Alternatives are then ranked with the help of calculated closeness coefficients.

Closeness coefficient is calculated with the following formula (1):

$$
C C_{i}=\frac{d_{i}^{-}}{d_{i}^{*}+d_{i}^{-}} \quad i=1,2, \ldots, m
$$

In (1), $C C_{\mathrm{i}}$ represents the relative proximity to the ideal solution, $d_{i}^{-}$represents the distance of each alternative i from the negative solution, $d_{i}^{*}$ indicates the distance of each alternative $i$ from the positive solution, $i$ represents alternative $i$ and $\mathrm{m}$ represents the number of alternatives.

Closeness coefficients take a value between 0 and 1 and used to rank the alternatives. Larger closeness coefficients can be defined as an indication of the alternative being preferred by decision makers (Paksoy et al., 2013).

The ranking obtained after the application of the fuzzy TOPSIS method indicates which activities should be prioritized in the action program. In this study, fuzzy TOPSIS results of environmental activities were also compared with only the E-FMEA results.

\section{APPLICATION RESULTS}

In this study, an approach was developed for enterprises that are willing to establish an EMS or to improve existing systems, which assists in answering the questions of "which activities should EMS's be composed of' and 'which activities should be prioritized'. The developed approach was applied to a chemical manufacturing company producing paint. However, the approach can be applied to any manufacturing sector.

While identifying environmental activities in the study, main topics about environmental management were initially established in every industrial field. Then, within the scope of these main topics, the content of IS0 14001 EMS standard, the requirements of the environmental legislation in force and studies in the literature were examined. In addition, final environmental activities were determined as a result of field surveys and face-to-face interviews conducted with 
the environmental specialist and environmental technician who worked in the company that is the subject of this study.

Table 5 shows the main topics and activities of EMS. The list includes the main topics of activity that are important in environmental management and the environmental improvement activities that should be undertaken by enterprises within these main topics.

As seen in Table 5, 10 main topics that are highly important in environmental management were identified. These topics include 'waste management, emission monitoring, waste water monitoring, electricity consumption monitoring, water consumption monitoring, natural gas/fuel usage, indoor environment cleaning, material usage, environmental management organization, and emergency management. 39 environmental activities were created based on these main topics.

In Table 5, within the main topic of 'waste management', environmental activities such as decomposition of wastes, transport of wastes to temporary storage area, disposal and recycling operations, physical compliance of waste storage area and management of hazardous and medical waste were identified. As part of emissions monitoring, environmental activities such as flue measurements, flue and filter maintenance within the context of monitoring emissions from burning flues or escape funnels on site and establishing ventilations systems and monitoring air quality in indoor working environments were created. In terms of waste water monitoring, processes such as operational activities in treatment plants treating domestic and industrial waste water produced from operational activities and monitoring water consumption, operational maintenance activities of treatment plants where domestic or industrial wastes are processed, and processes related to the chemicals to be used in these plants were identified as activity topics.

In Table 5, under the topic of monitoring electricity consumption, issues such as electricity consumption due to use of machinery and equipment and other activities, identification of energy leakages and taking necessary measures, monitoring energy efficiency of which has an increasing importance recently and monitoring alternative energy sources were identified as environmental activities. Under the topic of monitoring water consumption, issues such as monitoring water consumption from operational activities of the enterprise and processes outside the operational activities, and evaluation of water reusability within the process were identified as activities. Under the topic of natural gas/fuel usage, monitoring the consumption of natural gas and similar fuels was identified as an environmental activity. Under the topic of indoor environment cleaning, site cleanliness, disposal of wastes produced by cleaning activities, dust and VOC gas measurements arising from operational activities on site, and other environmental factors arising from operational activities such as noise-vibration were identified. Under the topic of material usage, selection of environmentally-friendly materials not harmful to nature and humans, promoting the usage of common parts to reduce raw material usage and wastes, and selection of recyclable materials were identified as environmental activities. Under the topic of environmental management organization, environmental activities identified included establishing site inspection systems, establishing procedures and guidelines related to environmental management, providing environmental training to employees, assigning personnel responsible for the environment, and creating an environmental budget for environmental activities. Lastly, under the topic of emergency management, activities such as establishing fire detection and firefighting systems, establishing chemical spillage cleaning sets, and performing regular environmental drills and practices were included.

Table 5. List of EMS main topics and activities

\begin{tabular}{|l|l|}
\hline Main Topics & Environmental Activities \\
\hline \multirow{3}{*}{ 1.Waste Management } & 1.1. Decomposition of wastes in production sites \\
\cline { 2 - 2 } & 1.2. Transport of wastes to temporary storage area \\
\cline { 2 - 2 } & 1.3. Storage of wastes in temporary storage area \\
\hline
\end{tabular}




\begin{tabular}{|c|c|}
\hline & 1.4. Waste recycling operations \\
\hline & 1.5. Waste disposal operations \\
\hline & 1.6. Ensuring physical compliance of waste storage area \\
\hline & 1.7. Implementation of hazardous waste management \\
\hline & 1.8. Control of medical wastes \\
\hline \multirow{4}{*}{ 2.Emissions Monitoring } & 2.1. Measuring operational emission values \\
\hline & 2.2. Cleaning/maintenance of flues \\
\hline & 2.3. Cleaning/maintenance of ventilation filters \\
\hline & 2.4. Creation of ventilation systems on the site \\
\hline Main Topics & Environmental Activities \\
\hline \multirow{4}{*}{ 3.Waste Water Monitoring } & 3.1. Measuring waste water discharge values \\
\hline & 3.2. Maintenance of treatment plant \\
\hline & 3.3. Measuring daily values of treatment plant \\
\hline & 3.4. Regular procurement of treatment plant equipment and chemical materials \\
\hline \multirow{4}{*}{$\begin{array}{l}\text { 4.Electricity Consumption } \\
\text { Monitoring }\end{array}$} & 4.1. Determination of electricity energy usage \\
\hline & 4.2. Prevention of energy leakage in machines \\
\hline & 4.3. Examination of alternative energy usage options \\
\hline & 4.4. Follow-up of energy efficiency \\
\hline \multirow{2}{*}{$\begin{array}{l}\text { 5.Water Consumption } \\
\text { Monitoring }\end{array}$} & 5.1. Follow-up of water consumption values \\
\hline & 5.2. Examination of recyclable water use in the process \\
\hline 6.Natural Gas/Fuel Usage & 6.1. Follow-up of natural gas/fuel usage \\
\hline \multirow{4}{*}{$\begin{array}{l}\text { 7.Indoor Environment } \\
\text { Cleaning }\end{array}$} & 7.1. Maintaining regular site cleanliness \\
\hline & 7.2. Indoor dust/gas measurements \\
\hline & 7.3. Disposal of site cleaning wastes \\
\hline & 7.4. Noise and vibration checks \\
\hline \multirow{3}{*}{ 8.Material Usage } & 8.1. Selection of materials with clean environment content \\
\hline & 8.2. Enabling use of common parts \\
\hline & 8.3. Selection of materials with recyclable content \\
\hline \multirow{5}{*}{$\begin{array}{l}\text { 9. Environmental } \\
\text { Management Organization }\end{array}$} & 9.1. Establishment of a site supervision system \\
\hline & 9.2. Preparation of procedures and instructions within the enterprise \\
\hline & 9.3. Providing periodical environmental training \\
\hline & 9.4. Identification of personnel responsible for the environment \\
\hline & 9.5. Creation of an environmental budget \\
\hline \multirow{4}{*}{ 10.Emergency Management } & 10.1. Establishing fire detection systems \\
\hline & 10.2. Establishing firefighting systems \\
\hline & 10.3. Possession of chemical waste cleaning equipment \\
\hline & 10.4. Performing environmental practices \\
\hline
\end{tabular}

The identified environmental activities include all essential elements for the creation and implementation of an effective EMS.

Five evaluation criteria were identified for assessing the level of importance of the environmental activities, which were identified as important for implementation of the EMS, from 
the enterprise's point of view. These criteria are 'ease of application of operational activities, implementation cost of operational activities, e-FMEA score, environmental sustainability effect, and the need for expertise for improvement activities'. 'Ease of application of operational activities' criteria refers to the ease of implementing improvement actions planned to address the problems and insufficiencies related to identified environmental activities. Ease of application covers issues such as the time, number and quality of personnel, equipment and expertise needed during the implementation of improvement activities. The 'implementation cost' needed to implement improvement activities was identified as a separate evaluation criterion. 'EFMEA score', where occurrence, severity and detectability factors of the FMEA method are calculated for environmental factors, was identified as a separate evaluation criterion. This criterion was particularly included in the assessment scale not to overlook the frequency of occurrence, weight of impact, and detecting difficulty of environmental risks related to the activities. 'Environmental sustainability effect' is very important in measuring the level at which implemented environmental activities can be turned into a routine operational activity of the enterprise. In accordance with the EMS, it is important that all activities are carried out cyclically and regularly. For this reason, 'sustainability' was defined as an evaluation criterion. The 'level of technical expertise' required while carrying out the improvement actions was also set as a separate evaluation criterion, as specialists may be needed, particularly in the implementation of emissions monitoring, waste management, and treatment plant operations.

The evaluation criteria can be changed during the implementation of the method. The evaluation criteria identified in this study were the result of field experience that the author had about EMS applications and interviews with field experts and environmental technicians who worked on the field.

In this study, evaluation of environmental activities based on the identified criteria was performed by the environmental engineer working as the environmental specialist of the business and the environmental technician assisting this officer with operational issues such as waste management, treatment plant operation. E-FMEA evaluation was conducted by the environmental specialist of the business.

Table 6 shows examples of the evaluation performed by the evaluators using Table 3 .

Table 6. Evaluation of environmental activities according to specified criteria

\begin{tabular}{|c|c|c|c|c|c|c|}
\hline \multicolumn{2}{|c|}{ Main Topics and Environmental Activities } & $\begin{array}{l}\text { Criterion } 1 \\
\text { (Value1/ } \\
\text { Value2) }\end{array}$ & $\begin{array}{l}\text { Criterion } 2 \\
\text { (Value1/ } \\
\text { Value2) }\end{array}$ & $\begin{array}{l}\text { Criterion } 3 \\
\text { (Value1) }\end{array}$ & $\begin{array}{l}\text { Criterion } 4 \\
\text { (Value1/ } \\
\text { Value2) }\end{array}$ & $\begin{array}{l}\text { Criterion } 5 \\
\text { (Value1/ } \\
\text { Value 2) }\end{array}$ \\
\hline \multirow[t]{3}{*}{$\begin{array}{l}\text { Waste } \\
\text { Management }\end{array}$} & $\begin{array}{l}\text { Decomposition of } \\
\text { wastes in } \\
\text { production sites }\end{array}$ & $4 / 3$ & $3 / 3$ & 90 & $4 / 5$ & $1 / 1$ \\
\hline & $\begin{array}{l}\text { Transport of } \\
\text { wastes to } \\
\text { temporary storage } \\
\text { area }\end{array}$ & $3 / 2$ & $3 / 2$ & 168 & $5 / 5$ & $2 / 1$ \\
\hline & $\begin{array}{l}\text { Storage of wastes } \\
\text { in temporary } \\
\text { storage area }\end{array}$ & $3 / 2$ & $3 / 4$ & 280 & $3 / 4$ & $1 / 2$ \\
\hline
\end{tabular}


As an example, the three environmental activities linked to the 'waste management' main activity are shown in Table 6 . In Table 6, related to the 'decomposition of wastes in production sites' activity, the significance score for the first criterion (ease of application) was evaluated as 4 by the first evaluator and as 3 by the second evaluator; the significance score for the second criterion (cost of implementation) were evaluated as 3 by both evaluators, the significance score for the fourth criterion (environmental sustainability effect) was evaluated as 4 by the first evaluator and as 5 by the second evaluator and the significance score for the fifth criterion (requirement of expertise) were evaluated as 1 by both evaluators. In the study, the first evaluator is the environmental expert of the enterprise and the second evaluator is the environmental technician of the work site. The E-FMEA scoring was made only by the environmental expert and the values for the probability, the frequency and the detectability for the specified activity were valued as 6,5 and 3, respectively. Total risk score was obtained as 90 by multiplying these three values.

The evaluations were then converted into fuzzy equivalents using Table 3. Table 7 shows the fuzzy equivalents of the evaluation results. In Table 7, the first three activities of the 'waste management' main activity are shown as examples. Here, for the 'decomposition of wastes in production sites' activity, the fuzzy equivalent of the 4 points given by the first evaluator is ' $6,8,10$ ' and the fuzzy equivalent of the 3 points given by the second evaluator is ' $3,5,7$ ' as indicated in Table 3. The average rating of the two evaluators is ' $4.5,6.5,8.5$ '. For the 'ease of application' criterion, as among the 39 environmental activities the highest score given is 10 , the average rating was normalized to ' $0.45,0.65,0.85$ ' by dividing by 10 as required by the fuzzy TOPSIS method. All other activities were normalized with the same methodology according to the evaluation criteria.

In the implementation of the fuzzy TOPSIS method, the weights of each evaluation criterion also need to be determined. The weights of the evaluation criteria were determined by evaluators who were environmental experts and environmental technicians and are shown in Table 8.

Table 7. Conversion of evaluator scores to fuzzy equivalents and their normalization

\begin{tabular}{|c|c|c|c|c|c|c|}
\hline \multicolumn{2}{|c|}{$\begin{array}{l}\text { Main Topics and } \\
\text { Environmental Activities }\end{array}$} & $\begin{array}{l}\text { Criterion } \\
\text { (Value1/ } \\
\text { Value2) }\end{array}$ & $\begin{array}{l}\text { Criterion } 2 \\
\text { (Value1/ } \\
\text { Value 2) }\end{array}$ & $\begin{array}{l}\text { Criterion } 3 \\
\text { (Value1) }\end{array}$ & $\begin{array}{l}\text { Criterion } 4 \\
\text { (Value1/ } \\
\text { Value2) }\end{array}$ & $\begin{array}{l}\text { Criterion } 5 \\
\text { (Value1/ } \\
\text { Value2) }\end{array}$ \\
\hline \multirow{3}{*}{ 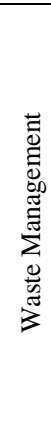 } & $\begin{array}{l}\text { Decomposition } \\
\text { of wastes in } \\
\text { production sites }\end{array}$ & $0.45,0.65,0.85$ & $0.30,0.50,0.70$ & $0.30,0.50,0.70$ & $0.70,0.90,1.00$ & $0,0,0.2$ \\
\hline & $\begin{array}{l}\text { Transport of } \\
\text { wastes to } \\
\text { temporary storage area }\end{array}$ & $0.15,0.35,0.35$ & $0.15,0.35,0.35$ & $0.60,0.80,1.00$ & $0.80,1.00,1.00$ & $0,0.1,0.3$ \\
\hline & $\begin{array}{l}\text { Storage of } \\
\text { wastes in } \\
\text { temporary storage area }\end{array}$ & $0.15,0.35,0.35$ & $0.45,0.65,0.85$ & $0.60,0.80,1.00$ & $0.45,0.65,0.85$ & $0,0.1,0.3$ \\
\hline
\end{tabular}

In Table 8, the first evaluator determined the significance level for 'ease of application' criterion as 'medium'. The weight value of 'medium' is ' $0.3,0.5,0.7$ ' as indicated in Table 4 . For the same criterion, the second evaluator determined the significance weight level as 'high'. The fuzzy weight value of 'high' is ' $0.8,0.8,1$ '. The arithmetic average of the values given by the two evaluators was found to be ' $0.55,0.650 .85$ '. 
Table 8. Fuzzy weights of criteria specified by the decision makers

\begin{tabular}{|l|l|l|l|}
\hline Evaluation Criteria & Evaluator I & Evaluator II & Average Score \\
\hline Ease of application & $0.30,0.50,0.70$ & $0.80,0.80,1.00$ & $0.55,0.65,0.85$ \\
\hline Cost of implementation & $0.80,0.80,1.00$ & $0.80,1.00,1.00$ & $0.80,0.90,1.00$ \\
\hline E-FMEA score sustainability & $0.80,0.80,1.00$ & $0.30,0.50,0.70$ & $0.55,0.65,0.85$ \\
\hline $\begin{array}{l}\text { Environmental } \\
\text { effect }\end{array}$ & $0.80,0.80,1.00$ & $0.30,0.50,0.70$ & $0.55,0.65,0.85$ \\
\hline Requirement of expertise & $0.30,0.50,0.70$ & $0.00,0.20,0.40$ & $0.15,0.35,0.55$ \\
\hline
\end{tabular}

The weighted normalized fuzzy decision matrix was created by multiplying the normalized fuzzy decision matrix elements given in Table 7 with the average weight values of the evaluation criteria in Table 8. An example of a weighted normalized decision matrix is given in Table 9. For example, the normalized value in Table 7 for 'decomposition of wastes in production sites' activity was found to be ' $0.45,0.65,0.85$ '. For the first evaluation criterion, which is 'ease of application', the average score values of the evaluators in Table 8 are ' $0.55,0.65,0.85$. By multiplying both fuzzy values ' $0.25,0.42,0.72$ ' was obtained.

Table 9. Example of weighted normalized decision matrix

\begin{tabular}{|c|c|c|c|c|c|c|}
\hline \multicolumn{2}{|c|}{$\begin{array}{l}\text { Main Topics and } \\
\text { Environmental Activities }\end{array}$} & $\begin{array}{l}\text { Criterion } \\
\text { (Value1/ } \\
\text { Value2) }\end{array}$ & $\begin{array}{l}\text { Criterion } 2 \\
\text { (Value1/ } \\
\text { Value2) }\end{array}$ & $\begin{array}{l}\text { Criterion } 3 \\
\text { (Value1) }\end{array}$ & $\begin{array}{l}\text { Criterion } 4 \\
\text { (Value1/ } \\
\text { Value 2) }\end{array}$ & $\begin{array}{l}\text { Criterion } 5 \\
\text { (Value1/ } \\
\text { Value 2) }\end{array}$ \\
\hline \multirow{3}{*}{ 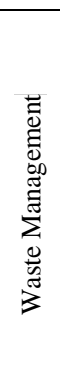 } & $\begin{array}{l}\text { Decomposition of wastes } \\
\text { in } \\
\text { production sites }\end{array}$ & $0.25,0.42,0.72$ & $0.24,0.45,0.70$ & $0.17,0.33,0.60$ & $0.56,0.72,1.00$ & $0.00,0.00,0.20$ \\
\hline & $\begin{array}{l}\text { Transport of } \\
\text { wastes to } \\
\text { temporary storage area }\end{array}$ & $0.08,0.23,0.47$ & $0.12,0.32,0.55$ & $0.33,0.52,0.85$ & $0.64,0.08,1.00$ & $0.00,0.10,0.30$ \\
\hline & $\begin{array}{l}\text { Storage of wastes in } \\
\text { temporary storage area }\end{array}$ & $0.08,0.23,0.47$ & $0.36,0.59,0.85$ & $0.33,0.52,0.85$ & $0.36,0.52,0.85$ & $0.00,0.10,0.30$ \\
\hline
\end{tabular}

After the evaluations, steps of the fuzzy TOPSIS method were respectively applied and evaluation scores of each environmental activity were calculated. Fuzzy TOPSIS results are shown in Table 10. In Table 10, $d_{i}^{*}$ represents the distance from the fuzzy positive solution, $d_{i}^{-}$ represents the distance from the negative ideal solution and $C C_{i}$ represents the relative proximity to the ideal solution.

In fuzzy TOPSIS method, for 5 evaluation criteria, fuzzy positive ideal solution set is $[(1,1,1)$, $(1,1,1),(1,1,1),(1,1,1),(1,1,1)]$ and fuzzy negative ideal solution set is $[(0,0,0),(0,0,0),(0,0,0)$, $(0,0,0),(0,0,0)]$. In Table 10 , the distances of each alternative value from the fuzzy positive solution and the fuzzy negative solution, $d_{i}^{*}$ and $d_{i}^{-}$respectively, are calculated. In Table 10, $d_{i}^{*}$ for Item 1.1 is 3.041 and calculated as follows.

$$
\begin{aligned}
d_{i}^{*}= & \sqrt{\frac{1}{3}\left[(1-0.25)^{2}+(1-0.42)^{2}+(1-0.72)^{2}\right.}+ \\
& \sqrt{\frac{1}{3}\left[(1-0.24)^{2}+(1-0.45)^{2}+(1-0.7)^{2}\right]}+
\end{aligned}
$$




$$
\begin{aligned}
& \left.\sqrt{\frac{1}{3}\left[(1-0.17)^{2}+(1-0.33)^{2}+(1-0.6)^{2}\right.}\right]+ \\
& \sqrt{\frac{1}{3}\left[(1-0.56)^{2}+(1-0.72)^{2}+(1-1)^{2}\right]}+ \\
& \sqrt{\frac{1}{3}\left[(1-0)^{2}+(1-0)^{2}+(1-0.2)^{2}\right]} .
\end{aligned}
$$

In the same Table $d_{i}^{-}$for Item 1.1 is 2.304 and calculated as follows.

$$
\begin{aligned}
& d_{i}^{-}= \sqrt{\frac{1}{3}\left[(0-0.25)^{2}+(0-0.42)^{2}+(0-0.72)^{2}\right.}+ \\
&\left.\sqrt{\frac{1}{3}\left[(0-0.24)^{2}+(0-0.45)^{2}+(0-0.7)^{2}\right.}\right]+ \\
&\left.\sqrt{\frac{1}{3}\left[(0-0.17)^{2}+(0-0.33)^{2}+(0-0.6)^{2}\right.}\right]+ \\
& \sqrt{\frac{1}{3}\left[(0-0.56)^{2}+(0-0.72)^{2}+(0-1)^{2}\right]}+ \\
& \sqrt{\frac{1}{3}\left[(0-0)^{2}+(0-0)^{2}+(0-0.2)^{2}\right]} .
\end{aligned}
$$

$\mathrm{CC}_{\mathrm{i}}$ value for Item 1.1 is calculated as 0.431 .

As indicated in Table 10, according to the fuzzy TOPSIS results, the significance scores of the top 10 important environmental activities are listed as 'establishing firefighting systems 0.651 , regular procurement of treatment plant test equipment and chemicals 0.630 , establishing ventilation systems on site 0.628 , enabling usage of common parts 0.606 , establishing fire detection systems 0.603 , noise and vibration monitoring 0.599 , measurement and monitoring of emission values 0.599 , treatment plant maintenance 0.588 , indoor dust and gas measurements 0.584 , prevention of energy leakage of machines 0.579 '. The average values of the results of the main environmental activities are listed in decreasing order as 'emissions monitoring 0.585, material usage 0.568 , waste water monitoring 0.561 , natural gas/fuel usage 0.457 , emergency management 0.549 , electricity consumption monitoring 0.541 , indoor environment cleaning 0.480 , waste management 0.473 , water consumption monitoring 0.433 ve environmental management organization 0.398 '.

When only E-FMEA method was applied, according to the magnitude of the risk scores the top 10 activities are listed as 'determination of electricity energy usage 512, implementation of hazardous waste management 448 , cleaning/maintenance of ventilation filters 448 , maintenance of treatment plant 448, follow-up of energy efficiency 432, measuring operational emission values 405 , cleaning/maintenance of flues 384 , prevention of energy leakage in machines 384 , measuring daily values of treatment plant 378 ve regular procurement of treatment plant equipment and chemical materials 336'. Average values of the results when only the main environmental activities are condired using only E-FMEA are listed in decreasing order as 'emissions monitoring 412.3, electricity consumption monitoring 404, waste water monitoring 360.5 , material usage 264, natural gas/fuel usage 252, emergency management 223, waste management 222.7, indoor environment cleaning 199.5, water consumption monitoring 197.5 environmental management organization 90.4'.

When the first 10 given by the fuzzy TOPSIS and E-FMEA methods were compared, 'maintenance of treatment plant, measuring operational emission values, prevention of energy leakage in machines, regular procurement of treatment plant equipment and chemical materials' were identified as common subjects. The differences are due to the effect of evaluation criteria in fuzzy TOPSIS that are not present in E-FMEA. As prioritizing environmental activities using different criteria is one of the purposes of this study, this also suggests a way for the enterprises 
to incorporate operational factors such as cost, labor, expertise requirements, sustainability etc. into their decision making prosesses when developing an improvement plan or deciding improvement plans to prioritize.

When the common characteristics of the top 10 activities according to fuzzy TOPSIS were evaluated, it was seen that their costs are high, they require expert knowledge, their applications involve complicated processes, they have high environmental risks, and they require continuity in terms of sustainability. The topics with the lowest evaluation score in the fuzzy TOPSIS analysis were activities with low implementation cost, that are easy to implement, do not require expertise, easily sustainable, and have low environmental risk, such as control of medical wastes, establishing environmental procedures and guidelines, assigning environmental officers, disposal of site cleaning wastes and establishing site inspection systems. This suggests that the analysis made provided appropriate results according to the determined criteria.

Table 10. Fuzzy TOPSIS results

\begin{tabular}{|c|c|c|c|c|c|c|c|c|c|}
\hline \multicolumn{2}{|l|}{ Activities } & $d_{1}^{*}$ & $d_{1}^{-}$ & $\mathrm{CC}_{1}$ & \multicolumn{2}{|l|}{ Activities } & $d_{1}^{*}$ & $d_{1}^{-}$ & $\mathrm{CC}_{1}$ \\
\hline \multirow{8}{*}{ 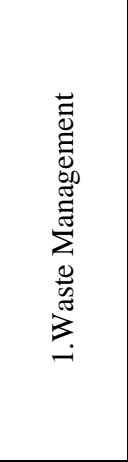 } & Item 1.1 & 3.041 & 2.304 & 0.431 & \multirow{8}{*}{ 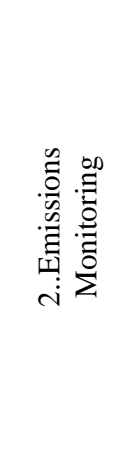 } & \multirow{2}{*}{ Item 2.1} & \multirow{2}{*}{2.144} & \multirow{2}{*}{3.208} & \multirow{2}{*}{0.599} \\
\hline & Item 1.2 & 3.049 & 2.292 & 0.429 & & & & & \\
\hline & Item 1.3 & 3.036 & 2.335 & 0.435 & & \multirow{2}{*}{ Item 2.2} & \multirow{2}{*}{2.312} & \multirow{2}{*}{3.088} & \multirow{2}{*}{0.572} \\
\hline & Item 1.4 & 2.791 & 2.586 & 0.481 & & & & & \\
\hline & Item 1.5 & 2.422 & 2.987 & 0.552 & & \multirow{2}{*}{ Item 2.3} & \multirow{2}{*}{2.464} & \multirow{2}{*}{2.915} & \multirow{2}{*}{0.542} \\
\hline & Item 1.6 & 2.494 & 2.881 & 0.536 & & & & & \\
\hline & Item 1.7 & 2.429 & 2.968 & 0.55 & & \multirow{2}{*}{ Item 2.4} & \multirow{2}{*}{2.004} & \multirow{2}{*}{3.393} & \multirow{2}{*}{0.629} \\
\hline & Item 1.8 & 3.341 & 2.004 & 0.375 & & & & & \\
\hline \multirow{4}{*}{ 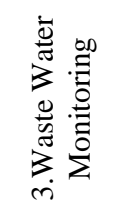 } & Item 3.1 & 2.53 & 2.877 & 0.532 & \multirow{4}{*}{ 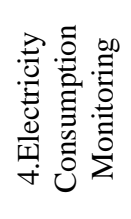 } & Item 4.1 & 2.733 & 2.618 & 0.489 \\
\hline & Item 3.2 & 2.209 & 3.155 & 0.588 & & Item 4.2 & 2.268 & 3.122 & 0.579 \\
\hline & Item 3.3 & 2.723 & 2.656 & 0.494 & & Item 4.3 & 2.562 & 2.855 & 0.527 \\
\hline & Item 3.4 & 1.997 & 3.411 & 0.631 & & Item 4.4 & 2.303 & 3.069 & 0.571 \\
\hline \multirow{2}{*}{ 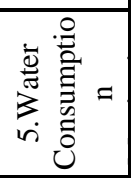 } & Item 5.1 & 3.012 & 2.356 & 0.439 & \multirow{2}{*}{ 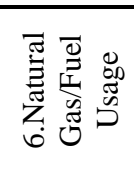 } & \multirow[b]{2}{*}{ Item 6.1} & \multirow[b]{2}{*}{2.923} & \multirow[b]{2}{*}{2.462} & \multirow[b]{2}{*}{0.457} \\
\hline & Item 5.2 & 3.073 & 2.305 & 0.429 & & & & & \\
\hline \multirow{4}{*}{ 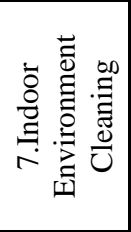 } & Item 7.1 & 3.254 & 2.072 & 0.389 & \multirow{4}{*}{ 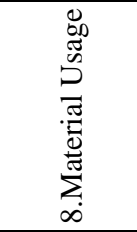 } & \multirow{2}{*}{ Item 8.1} & \multirow{2}{*}{2.34} & 2072 & $0-560$ \\
\hline & Item 7.2 & 2.242 & 3.16 & 0.585 & & & & 3.073 & 0.500 \\
\hline & Item 7.3 & 3.483 & 1.856 & 0.348 & & Item 8.2 & 2.128 & 3.279 & 0.606 \\
\hline & Item 7.4 & 2.187 & 3.275 & 0.6 & & Item 8.3 & 2.522 & 2.862 & 0.532 \\
\hline$\pi$ & Item 9.1 & 3.751 & 1.583 & 0.297 & & Item 101 & 2158 & 3282 & 0603 \\
\hline 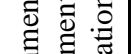 & Item 9.2 & 3.406 & 1.944 & 0.363 & 苛 & & & & \\
\hline : & Item 9.3 & 2.7 & 2.715 & 0.501 & छ & Item 10.2 & 1.883 & 3.516 & 0.651 \\
\hline जี $\sum^{\pi}$ & Item 9.4 & 3.469 & 1.885 & 0.352 & $\underbrace{0}$ & Item 10.3 & 2.733 & 2.664 & 0.494 \\
\hline & Item 9.5 & 2.812 & 2.603 & 0.481 & & Item 10.4 & 2.95 & 2.408 & 0.449 \\
\hline
\end{tabular}

According to these results, an enterprise that determines their priorities for environmental activities can increase their effectiveness in environment management by analyzing the current 
situation, determining the actions to be taken, solution times, solution methods and people who will implement it during the start of an improvement plan.

When applying the specified method, an enterprise may re-adjust both the activity list evaluation criteria in line with the organizational and management structure, the characteristics of the sector, the resources of the enterprise, the expectations of the senior management, the regulations related to the environmental management, and the expectations of the enterprise on environmental management. The method provides this flexibility.

\section{CONCLUSIONS}

In this study, a list of environmental activities was created for enterprises that want to establish an environmental management system or to improve their existing ones and fuzzy TOPSIS method together with evaluation criteria, which have not been used before, was used to determine which ones are more important. 10 main environmental activities and 39 sub-activities related to these main activities were examined in the study.

In this study, subjects that contribute to the literature and which can be further developed in different researches were established. First of all, the environmental activity list was created as a result of IS0 14001 EMS standard, current environmental legislation requirements, literature research, face to face interviews with environmental experts and environmental technicians and field evaluations. The prepared list can be used for the purpose of conducting an audit in the existing EMS structure of an enterprise, or it can be used as a reference during the establishment of a new system during the planning stage. In addition, this list can easily be adopted to any sector. While the EMS activities created include general topics, in accordance with the company's own resources, operational activities, maturity of the current EMS, and future stratejic objectives it can be updated.

One of the important contributions of this study to the literature is the evaluation criteria used. In this study, the evaluation criteria used in the ranking of the importance of activities as ' ease of implementation of improvement activities, implementation cost of improvement activities, EFMEA score, environmental sustainability effect, and expertise requirements for the improvement activities' are original evaluation criteria that have not been used in a different scientific study before. Independently of the sector, these criteria can be accepted by each enterprise and can be included in the analysis after deleting some of the criteria or by adding new ones.

The environmental risks or important environmental elements of an enterprise can be examined through risk assessment methods such as E-FMEA. However, in terms of environmental risk assessments, such methods ignores the subjects such as the financial status of the enterprise, the potential to allocate budget for the necessary improvement plans, the ease of implementation of an enterprise's improvement action, the impact of an improvement action on environmental sustainability, the use of existing labor force or the necessity of external expertise. It will not be appropriate to start prioritized activities by identifying environmental risks considering the financial, labor, time and technical capacity of the enterprises. For this reason, in this study, it is proposed to evaluate environmental activities with multi-criteria decision making approach.

When the first 10 activities were examined in order of importance among 39 environmental activities identified in the study, the fuzzy TOPSIS and E-FMEA results are common in 'maintenance of treatment plant, measuring operational emission values, prevention of energy leakage in machines, regular procurement of treatment plant equipment and chemical materials'. One of the main objectives of this study is while determining the important factors and improvement activities for enterprises, to include in the evaluation not only environmental risks but also cost, implementation time, ease of implementation, and labor force suitability. Different results Show that the fuzzy TOPSIS method directs the result according to the expectations possibilities of the enterprise. 
The environmental activity list created in this study is limited to be examined only within the framework of the specified criteria. In different studies, both the list of activities and the number and content of the evaluation criteria can be changed.

The sequential values obtained by fuzzy TOPSIS as a reult of the applied method can give similar values as in fuzzy TOPSIS and most multi-criteria evaluation methods. For example, in the study, the activity having the second highest fuzzy TOPSIS significance score had 0.630 as its significance weight and the activity having the third highest fuzzy TOPSIS significance score had 0.628. Analyzing these similar values in future studies by categorizing/clustering the importance levels rather than by ordering will contribute to the development of the research in this field.

\section{ACKNOWLEDGEMENTS}

We would like to thank the company and the company's environmental officers for their contributions and participating in this study.

\section{REFERENCES}

1. Aung, T. S., Luan, S., Xu, Q. (2019) Application of multi-criteria decision approach for the analysis of medical waste management systems in Myanmar, Journal of Cleaner Production, 222, 733-745. https://doi.org/10.1016/j.jclepro.2019.03.049

2. Amores-Salvado, J., Castro, G.M., Navas-López, J.E. (2015) The importance of the complementarity between environmental management systems and environmental innovation capabilities: A firm level approach to environmental and business performance benefits, Technological Forecasting \& Social Change, 96, 288-297. http://dx.doi.org/10.1016/j.techfore.2015.04.004

3. Balana, B.B., Mathijs, E., Muys, B. (2010) Assessing the sustainability of forest management: An application of multi-criteria decision analysis to community forests in Northern Ethiopia, Journal of Environmental Management, 91, 1294-1304. https://doi.org/10.1016/j.jenvman.2010.02.005

4. Chung, C., Hsieh, Y., Lin, H.C. (2019) Fuzzy inference system for modeling the environmental risk map of air pollutants in Taiwan, Journal of Environmental Management, 246, 808-820. https://doi.org/10.1016/j.jenvman.2019.06.038

5. Daddi, T., Testa, F., Frey, M., Iraldo, F. (2016) Exploring the link between institutional pressures and environmental management systems effectiveness: An empirical study, Journal of Environmental Management, 183, 647-656. http://dx.doi.org/10.1016/j.jenvman.2016.09.025

6. Darbra, R.M., Ronza, A., Stojanovic, T.A., Wooldridge, C., Casal, J. (2005) A procedure for identifying significant environmental aspects in sea ports, Marine Pollution Bulletin, 50, 866874. https://doi.org/10.1016/j.marpolbul.2005.04.037

7. Disterheft, A., Caeiro, S., Rosario Ramos, M., Azeiteiro, M. (2012) Environmental Management Systems (EMS) implementation processes and practices in European higher education institutions-Top Down versus participatory approaches, Journal of Cleaner Production, 31, 80-90. https://doi.org/10.1016/j.jclepro.2012.02.034

8. Erdas, C., Fokaides, P.A., Charalambous, C. (2015) Ecological footprint analysis based awareness creation for energy efficiency and climate change mitigation measures enhancing the environmental management yystem of Limassol Port, Journal of Cleaner Production, 108, 716-724. https://doi.org/10.1016/j.jclepro.2015.07.087 
9. Feng, T., Cai, D., Wang, D., Zhang, X. (2016) Environmental management systems and financial performance: the Joint effect of switching cost and competitive intensity, Journal of Cleaner Production, 113, 781-791. https://doi.org/10.1016/j.jclepro.2015.11.038

10. Gonzalez-Benito, J., Gonzalez-Benito, O. (2005) The role of stakeholder pressure and managerial values in the implementation of environmental logistics practices, International Journal of Production Research, 44, 1353-1373. https://doi.org/10.1080/00207540500435199

11. Guerrero-Baena, M.D., Gomez-Limon, J.A., Fruet, J.V. (2015) A multicriteria method for environmental management system selection: An intellectual capital approach, Journal of Cleaner Production, 105, 428-437. https://doi.org/10.1016/j.jclepro.2014.07.079

12. Interlenghi, S.F., Almeida Bruno, P., Queiroz Fernandes Araujo, O., Medeiros, J.L. (2017) Social and environmental impacts of replacing transesterification agent in soybean biodiesel production: Multi-criteria and principal component analyses, Journal of Cleaner Production, 168, 149-162. https://doi.org/10.1016/j.jclepro.2017.08.222

13. He, L., Shen, J., Zhang, Y. (2017) Ecological vulnerability assessment for ecological conservation and environmental management, Journal of Environmental Management, 206, 1115-1125. https://doi.org/10.1016/j.jenvman.2017.11.059

14. Karaer, F., Pusat, T. (2002) ISO 14001 Çevre yönetim sistemi standardının otomotiv yan sanayiine uygulanması. Uludă Üniversitesi Mühendislik-Mimarlık Fakültesi Dergisi, 7(1), $11-20$

15. Khalili, N.R. and Duecker, S. (2013) Application of multi-criteria decision analysis in design of sustainable environmental management system framework, Journal of Cleaner Production, 47, 188-198. http://dx.doi.org/10.1016/j.jclepro.2012.10.044

16. Kania, A., Roszak, M., Spilka, M. (2014) Evaluation of FMEA methods used in the environmental management, Materials Science and Engineering, 65, 37-44

17. Kanyimba, A.T., Richter, B.W., Raath, S.P. (2014) The effectiveness of an environmental management system in selected South African primary schools, Journal of Cleaner Production, 66, 479-488.

18. Kokangül, A., Polat, U., Dağsuyu, C. (2018) A new approach for environmental risk assessment, Human and Ecological Risk Assessment: An International Journal, 24, 90-104. https://doi.org/10.1080/10807039.2017.1364132

19. Ligus, M., Peternek, P. (2018) Determination of most suitable low-emission energy technologies development in Poland using integrated fuzzy AHP-TOPSIS method, Energy Procedia, 153, 101-106. https://doi.org/10.1016/j.egypro.2018.10.046

20. Lo, C.K.Y., Yeung, A.C.L., Cheng, T.C.E. (2012) The impact of environmental management systems on financial performance in fashion and textiles industries, Int. J. Production Economics, 135, 561-567. https://doi.org/10.1016/j.ijpe.2011.05.010

21. Marazza, D., Bandini, V., Contin, A. (2010) Ranking environmental aspects in environmental management systems: A new method tested on local authorities, Environment International, 36, 168-179. https://doi.org/10.1016/j.envint.2009.10.011

22. Martins, F.,Fonseca, L. (2018) Comparison between eco-management and audit scheme and ISO 14001:2015, Energy Procedia, 153, 450-454. https://doi.org/10.1016/j.egypro.2018.10.023

23. Mazzi, A., Toniolo, S., Mason, M., Aguiari, F., Scipioni, A. (2016) What are the benefits and difficulties in adopting an environmental management system? The opinion of Italian 
organizations, Journal of Cleaner Production, 139, 873-885. https://doi.org/10.1016/j.jclepro.2016.08.053

24. Mazzi, A., Toniolo, S., Catto, S., Lorenzi, V., Scipioni, A. (2017) The combination of an environmental management system and life cycle assessment at the territorial level, Environmental Impact Assessment Review, 63, 59-71. https://doi.org/10.1016/j.eiar.2016.11.004

25. Mohammed, M. (2000) The ISO 14001 EMS implementation process and its implications: A case study of Central Japan, Environmental Management, 25, 177-188. https://doi.org/10.1007/s002679910014

26. Oliveira, J.A., Oliveira, O.J., Ometto, A.R., Ferraudo, A.S., Salgado, M.H. (2016) Environmental management system ISO 14001 factors for promoting the adoption of cleaner production practices, Journal of Cleaner Production, 133, 1384-1394. http://dx.doi.org/ 10.1016/j.jclepro.2016.06.013

27. Orcos, R., Perez-Aradros, B., Blind, N. (2018) Why does the diffusion of environmental management standards differ across countries? The role of formal and informal institutions in the adoption of ISO 14001, Journal of World Business, 53, 850-861. http://dx.doi.org/10.1016/j.jwb.2018.07.002

28. Paksoy, T., Yapıcı Pehlivan, N., Özceylan, E. (2013) Bulanık Küme Teorisi, Nobel Yayınevi.

29. Phan, T.N. and Baird, K. (2015) The comprehensiveness of environmental management systems: The influence of institutional pressures and the impact on environmental performance, Journal of Environmental Management, 160, 45-56. http://dx.doi.org/ 10.1016/j.jenvman.2015.06.006

30. Roszak, M., Spilka, M., Kania, A. (2015) Environmental Failure Mode and Effects Analysis (FMEA)-A new approach to methodology, Metalurgija, 54, 449-451

31. Silva, S. and Lopes, A.M. (2017) Enviromental aspects and impacts of a waste incineration plant, Energy Procedia, 136, 239-244. https://doi.org/10.1016/j.egypro.2017.10.250

32. Qi, G.Y., Zeng, S.X., Tam, C.M., Yin, H.T., Wu, J.F., Dai, Z.H. (2011) Diffusion of ISO 14001 environmental management systems in China: Rethinking on stakeholders' roles, Journal of Cleaner Production, 19, 1250-1256. https://doi.org/10.1016/j.jclepro.2011.03.006

33. Wagner, M. (2015) A European perspective on country moderation effects: Environmental management systems and sustainability-related human resource benefits, Journal of World Business, 50, 379-388. http://dx/doi.org/ 10.1016/j.jwb.2014.08.005

34. Treacy, R., Humphreys, P., McIvor, R., Lo, C. (2019) ISO 14001 certification and operating performance: A practice-based view, International Journal of Production Economics, 208, 319-328. https://doi.org/10.1016/j.ijpe.2018.12.012

35. Vavrek, R., Chovancova, J. (2019) Assessment of economic and environmental energy performance of EU countries using CV-TOPSIS technique, Ecological Indicators, 106. https://doi.org/10.1016/j.ecolind.2019.105519

36. Yan, C. and Yanli, Z. (2011) Analysis on the environmental effect of renewable energy consumption by rural residents in daily life in China-from the perspectives of carbon emissions, Energy Procedia, 5, 1642-1646. http://dx.doi.org/ 10.1016/j.egypro.2011.03.280

37. Zackrisson, M. (2003) Environmental aspects when manufacturing products mainly out of metals and/or polymers, Journal of Cleaner Production, 13, 43-49. https://doi.org/10.1016/j.jclepro.2003.09.014 
Uludağ University Journal of The Faculty of Engineering, Vol. 25, No. 1, 2020

38. Zeng, S.X., Tam, C.M., Tam, V.W. (2015) Integrating safety, environmental and quality risks for project management using a FMEA method, Engineering Economics, 66 (1), 44-52 
